\title{
Gender disparity effect among financially included (and excluded) women in the Middle East and North Africa
}

\author{
Antonella Francesca Cicchiello, ${ }^{1, *}$ Amirreza Kazemikhasragh ${ }^{2} \bullet$ \\ Anna Maria Fellegara ${ }^{1} \cdot$ Stefano Monferrà ${ }^{1}$ \\ ${ }^{1}$ Università Cattolica del Sacro Cuore, Italy \\ ${ }^{2}$ National Autonomous University of Mexico (UNAM), Mexico
}

Received: 26 October 2020

Revised: 27 February 2021

Accepted: 5 April 2021

\begin{abstract}
Using the 2017 World Bank's Global Findex database, this study aims to investigate the effect of gender disparity on the financial inclusion (and exclusion) of women in a sample of 16 countries in the Middle East and North Africa (MENA) region. The results of the probit models suggest the existence of significant gender gaps in the access to and use of formal and informal financial services such as the ownership of financial institution accounts, mobile money accounts, credit card, and the usage of savings and credit products. Being a woman reduces the probability of having an account at a financial institution or through a mobile money provider, of formally saving at a financial institution, and of taking loans regardless of purpose. However, being a woman increases the probability of owning a credit card and saving semi-formally, by using a savings club or a person outside the family. Our analysis also highlights that the lack of enough money, religious concerns, and the fact that a family member already has an account are the most relevant factors in explaining the financial exclusion of women in the countries analysed. The findings of this study are beneficial for policymakers to promote financial inclusion for women and remove the barriers they face to access and use financial services. Reducing gender disparity in financial inclusion is crucial to enhance women's economic empowerment and promote inclusive development across emerging markets and developing economies of the MENA region.
\end{abstract}

Keywords: Gender; Financial inclusion; Discrimination; Emerging markets JEL Classification Codes: G21, J16, O16, O23

\section{Introduction}

Despite evident progress, women still face multiple barriers to financial inclusion especially in developing countries, where gender inequalities in the access and use of financial services are

\footnotetext{
*Corresponding author. E-mail: antonella.cicchiello@unicatt.it.
}

Citation: Cicchiello, A. A., Kazemikhasragh, A., Fellegara, A. M., and Monferrà, S. (2021) Gender disparity effect among financially included (and excluded) women in the Middle East and North Africa, Economics and Business Letters, 10(4), 342-348.

DOI: 10.17811/ebl.10.4.2021.342-348 
exacerbated by lower women's literacy, employment and access to technology (Klapper and Hess, 2016).

According to Demirgüç-Kunt et al. (2018), only 59\% of women own a bank account compared to $79 \%$ of men who handle $80 \%$ of the volume of loans and $75 \%$ of deposits. Furthermore, over 70 percent of women-owned small and medium enterprises (SMEs) have inadequate or no access to financial services (Koch et al., 2014).

The literature widely recognizes that removing gender gap in financial inclusion is essential to promote women's economic and social empowerment and boost countries' development (Ghosh and Vinod, 2017). Better financial inclusion may give women greater autonomy in deciding on personal and family life matters ranging from education and employment to whether to use their time in income-generating activities (Holloway et al., 2017). Furthermore, greater financial inclusion contributes significantly to close the credit gap for female-owned SMEs increasing employment as well as innovation and productivity of developing economies (Koch et al., 2014). Digital financial technologies can be powerful tools to foster women's financial inclusion, reducing or even eliminating the gender gaps in account ownership (Klapper and Hess 2016). These technologies allow to overcome the restrictions imposed by geography, reduce the transaction costs of using financial services and improve transparency and therefore increase trust in financial systems. According to Suri and Jack (2016), the introduction of mobile money services in Kenya has increased per capita consumption levels and lifted $2 \%$ of households (especially those female-headed) out of poverty.

However, financial inclusion also requires large government programs and localized solutions that foster social norm change and intra-household communication strategies as well as significant investments in women's literacy and autonomy that enable them to retain control over their earnings and savings (Arnold and Gammage, 2019).

Using data from the MENA region, we analyze the relationship between gender and financial inclusion and the factors that influence it. Our results confirm the existence of a gender gap in financial inclusion and that economic and cultural discrimination contributes significantly to this gap. Our paper contributes to the expanding literature on the determinants of financial inclusion by focusing on emerging markets and developing economies of the MENA region. Some studies have investigated financial inclusion in several countries (e.g., Zins and Weill, 2016) but similar research has not been carried out in the context of the MENA region. We also give new evidence on the determinants of credit cards ownership which is of prime interest considering that their use might affect the demand for and use of short-term credit in developing economies and provide account owners with a convenient way to make payments without having to withdraw cash. Finally, we investigate the usage of semi-formal savings (i.e., savings made by using a savings club or a person outside the family). Such investigation is crucial as semi-formal savings represents a common alternative to saving at a financial institution in developing economies especially for women (Demirgüç-Kunt et al., 2018).

\section{Data}

This study uses data from the 2017 World Bank's Global Findex database, compiled using nationally representative surveys of more than 150,000 adults age 15 and above in over 140 economies around the world. The data provides insight on access to and use of formal and informal financial services.

16 countries of the emerging markets and developing economies in the Middle East and North Africa are considered for our analysis (Afghanistan, Algeria, Bahrain, Egypt, Iran, Iraq, Jordan, Kuwait, Lebanon, Libya, Mauritania, Morocco, Pakistan, Saudi Arabia, Tunisia, United Arab Emirates). We used Stata to analyze the data and the probit model to identify the degree of financial inclusion in the selected countries. 


\section{Methods}

To analyse and determine the extent of financial inclusion in the least developed countries in the MENA region, we perform probit estimations using the following model:

$$
X_{i}=\alpha+\beta G_{i}+\gamma A_{i}+\eta I_{i}+\theta E_{i}+\lambda R_{i}+\rho L_{i}+\varepsilon_{i}
$$

Where: $X$ represents the financial inclusion and $i$ represents one given individual, $G$ represents the gender, $A$ is the age, $I$ represents the income, $E$ represents the education level, $R$ represents the rural (versus urban) residence, $L$ represents the employment status (in or out the labor force), and $\varepsilon_{i}$ represents the error term.

In line with previous studies (e.g., Abdu et al., 2015; Zins and Weill, 2016), as main measures of financial inclusion we use nine dummy variables taking values 1 if the individual: owns a "financial institution account", a "mobile money account", or a "credit card"; has "Saved any money in the past 12 months" at a financial institution "Formal saving" or by using a savings club or a person outside the family "Semi-formal saving"; has borrowed money for "health purposes", to "start, operate, or expand a farm", or for "education or school fees".

The gender variable is a dummy taking value 1 if the individual is a woman, and 0 otherwise.

We control for a range of individual characteristics, including income, age, education, rural residency and employment status. To measure the age, we use two dummy variables: young adults (between 15 and 24 years old) and older adults (more than 25 years old). For the income we use two dummy variables: "Poorest 40\%" and "Richest 60\%". To measure the relationship between the level of education and financial inclusion we use two dummy variables representing the "Primary school or less" and "Secondary education or more", respectively.

We include a dummy variable for rural (versus urban) residence. For the employment status we use two dummy variables: "in the labor force" and "out of the labor force".

To measure barriers to financial inclusion, we estimate eight dummy variables relating to the reasons why Respondents to the 2017 Global Findex survey are unbanked (do not have an account at a financial institution or through a mobile money provider): excessive distance to the formal financial institutions "Too far away"; "Too expensive" costs; lack of: "Documentation", "Trust", "Money", and "Need for financial services"; "Religious reasons"; and the fact that "A family member has an account" and the individual uses it.

Some of the reasons why people are unbanked depend on their personal choices while other have been imposed on them due to different circumstances.

Table 1 shows the descriptive statistics of all variables used for the analysis. $47.2 \%$ of individuals own an account at a formal financial institution, $34.2 \%$ a credit card and $14.5 \%$ a mobile money account. $40.4 \%$ of individuals have completed primary school or less and $39.6 \%$ their tertiary education or more. People save money (99.6\%). $14.9 \%$ resort to formal, $89.6 \%$ rely on semi-formal savings. People borrow money mainly for health purposes $(11.4 \%)$ and to education and school fees (10\%). 5.4\% of people borrow money to start, operate, or expand a farm. The main barrier to financial inclusion is represented by the lack of sufficient funds $(67.2 \%)$ followed by the lack of need to use financial services (28.3\%), high costs (23.4\%) and a family member who already has an account (15\%). Further barriers are represented by lack of documentation and trust (14\%), excessive distance of financial institutions (13.4\%), and religious reasons $(8.8 \%)$.

\section{Results}

Table 2 presents the results and the marginal effects of the probit models of determinants of financial inclusion. Marginal effects refer to the impact of the regressors on the probability of the variables of financial inclusion (Abdu et al., 2015). 
Table 1. Descriptive statistics of the variables.

\begin{tabular}{lccc}
\hline \hline Variable & Obs. & Mean & St. Dev. \\
\hline Dependent variables & & & \\
\hline Financial Institution Account & 20,817 & .4722583 & .4992418 \\
Mobile Money Account & 20,817 & .1451558 & .3522599 \\
Credit card ownership & 20,817 & .3427331 & .4196571 \\
\hline Loan motivation & & & \\
\hline Borrowed for health purpose & 14,734 & .1143296 & .3182188 \\
Borrowed to start, operate, or expand a farm & 20,817 & .0549551 & .2278980 \\
Borrowed for education or school fees & 20,817 & .1013114 & .3017479 \\
\hline Barriers & & & \\
\hline Too far away & 11,605 & .1348557 & .3415841 \\
Too expensive & 11,605 & .2347264 & .4238460 \\
Lack of necessary documentation & 11,605 & .1403705 & .3473860 \\
Lack of trust & 11,605 & .1405407 & .3526604 \\
Insufficient funds & 11,605 & .6723826 & .4693647 \\
Religious reasons & 11,605 & .0887548 & .2844018 \\
Someone in the family has an account & 11,605 & .1512279 & .3582863 \\
No need for financial services & 11,605 & .2835847 & .4507570 \\
\hline Saving & & & \\
\hline Formal savings & 20,817 & .1491089 & .3562043 \\
Semi-formal savings & 13,739 & .8963534 & .3048126 \\
Any money saved in the past 12 months & 20,817 & .9965893 & .0583027 \\
Explanatory variables & & & \\
\hline Individual characteristics & & & \\
\hline Female & 20,817 & .4708652 & .4991624 \\
\hline Income: & & & \\
\hline Poorest 40\% & 20,817 & .4049873 & .4965231 \\
Richest 60\% & 20,817 & .5950127 & .4532976 \\
\hline Education: & & & \\
\hline Primary school or less & 20,817 & .4043330 & .4907743 \\
Secondary education or more & 20,817 & .3961186 & .4891014 \\
\hline Age: & 20,799 & .5489654 & .3365984 \\
\hline Young adults & 20,799 & .4510341 & .3610829 \\
\hline Older adults & 20,817 & .3745177 & \\
\hline Rural residence & & & \\
\hline Employment status: & 20,817 & .396742 \\
In the labor force & & .3496248 & \\
\hline \hline & & & \\
\hline Sout of the labor force & & & \\
\hline
\end{tabular}

Source: Authors' elaboration on STATA output.

Overall, the results suggest that women are less likely to be financially included than men, especially in the formal financial markets since they might not be able to meet the requirements of formal institutions to access their services.

Gender dynamics hold women back on both accounts (i.e., financial institution accounts and mobile money accounts).

However, women are positively and significantly associated with credit card ownership used to obtain short-term credit as an alternative to loans from financial institutions.

With account ownership being a prerequisite for formal saving, it is no surprise that women, who are less likely to have an account than men, also are less likely to save formally at a financial institution. This gender gap in formal saving therefore reflects the gender gap in account ownership. 
Table 2. Determinant of financial inclusion (robust standard errors in parentheses).

\begin{tabular}{|c|c|c|c|c|c|c|c|c|c|}
\hline & $\begin{array}{r}\text { Financial } \\
\text { institution } \\
\text { accounts }\end{array}$ & $\begin{array}{r}\text { Mobile } \\
\text { money } \\
\text { accounts }\end{array}$ & $\begin{array}{r}\text { Credit } \\
\text { card } \\
\text { ownership }\end{array}$ & $\begin{array}{l}\text { Formal } \\
\text { savings }\end{array}$ & $\begin{array}{r}\text { Semi- } \\
\text { formal } \\
\text { savings }\end{array}$ & $\begin{array}{r}\text { Any money } \\
\text { saved in } \\
\text { the past } 12 \\
\text { months }\end{array}$ & $\begin{array}{c}\text { Borrowed } t \\
\text { for health: } \\
\text { purpose }\end{array}$ & $\begin{array}{r}\text { Borrowed } \\
\text { to start, op- } \\
\text { rate, or ex- } \\
\text { pand a } \\
\text { farm } \\
\end{array}$ & $\begin{array}{r}\text { Borrowed } \\
\text { for educa- } \\
\text { tion or } \\
\text { school fees }\end{array}$ \\
\hline Female & $\begin{array}{r}-.48 * * \\
(.29)\end{array}$ & $\begin{array}{r}-.38 * * \\
(.15)\end{array}$ & $\begin{array}{l}.08^{*} \\
(.03)\end{array}$ & $\begin{array}{r}-.27 * * \\
(.19)\end{array}$ & $\begin{array}{l}.31 * * \\
(.19)\end{array}$ & $\begin{array}{r}-.08 * * \\
(.05)\end{array}$ & $\begin{array}{r}-.19 * * \\
(.07)\end{array}$ & $\begin{array}{r}-.53 * * \\
(.27)\end{array}$ & $\begin{array}{r}-.36^{* *} \\
(.24)\end{array}$ \\
\hline Poorest $40 \%$ & $\begin{array}{r}-.47 * \\
(.31)\end{array}$ & $\begin{array}{r}-.79 * * \\
(.56)\end{array}$ & $\begin{array}{r}-.08 * * \\
(0.03)\end{array}$ & $\begin{array}{r}-.28 * * \\
(.16)\end{array}$ & $\begin{array}{r}-.14 \\
(.11)\end{array}$ & $\begin{array}{r}-.31 * * \\
(.23)\end{array}$ & $\begin{array}{r}.27 * * \\
(.13)\end{array}$ & $\begin{array}{r}-.34 * * \\
(.28)\end{array}$ & $\begin{array}{r}-.35^{* *} * \\
(.29)\end{array}$ \\
\hline Richest $60 \%$ & $\begin{array}{r}-.24 * * \\
(.15)\end{array}$ & $\begin{array}{r}-.29 * * \\
(.14)\end{array}$ & $\begin{array}{r}.19 * * \\
(.14)\end{array}$ & $\begin{array}{r}.32 * * \\
(.24)\end{array}$ & $\begin{array}{r}.23 * * * \\
(.17)\end{array}$ & $\begin{array}{r}.46^{* * *} \\
(.27)\end{array}$ & $\begin{array}{l}.36^{*} \\
(.29)\end{array}$ & $\begin{array}{r}-.08 * * \\
(.04)\end{array}$ & $\begin{array}{r}-.16 * * \\
(.09)\end{array}$ \\
\hline $\begin{array}{l}\text { Primary } \\
\text { education or } \\
\text { less }\end{array}$ & $\begin{array}{r}.29 * * \\
(.16)\end{array}$ & $\begin{array}{r}.18^{* *} \\
(.09)\end{array}$ & $\begin{array}{r}.07 * * \\
(.04)\end{array}$ & $\begin{array}{r}-.04 * * \\
(.02)\end{array}$ & $\begin{array}{r}.18 * * \\
(.09)\end{array}$ & $\begin{array}{r}.04 * * \\
(.01)\end{array}$ & $\begin{array}{r}-.02 * * \\
(.01)\end{array}$ & $\begin{array}{r}-.48 * * \\
(.19)\end{array}$ & $\begin{array}{r}-.01 * * \\
(.01)\end{array}$ \\
\hline $\begin{array}{l}\text { Secondary } \\
\text { education or } \\
\text { more }\end{array}$ & $\begin{array}{l}.53 * * \\
(.28)\end{array}$ & $\begin{array}{r}.43 * * \\
(.22)\end{array}$ & $\begin{array}{r}.18 * * \\
(.16)\end{array}$ & $\begin{array}{r}.24 * * \\
(.17)\end{array}$ & $\begin{array}{c}.42 * * \\
(.28)\end{array}$ & $\begin{array}{r}.23 * * \\
(.18)\end{array}$ & $\begin{array}{r}-.33 * * \\
(.14)\end{array}$ & $\begin{array}{r}-.29 * * \\
(.17)\end{array}$ & $\begin{array}{r}.07 * * \\
(.02)\end{array}$ \\
\hline $\begin{array}{l}\text { Young } \\
\text { adults }\end{array}$ & $\begin{array}{r}.02 * * \\
(.01)\end{array}$ & $\begin{array}{r}.08 * * \\
(.03)\end{array}$ & $\begin{array}{r}.05^{* *} \\
(.01)\end{array}$ & $\begin{array}{r}.01 * * \\
(.01)\end{array}$ & $\begin{array}{r}.07 * * \\
(.03)\end{array}$ & $\begin{array}{r}.02 * * \\
(.01)\end{array}$ & $\begin{array}{r}-.14 * * \\
(.07)\end{array}$ & $\begin{array}{r}-.03 * * \\
(.01)\end{array}$ & $\begin{array}{r}-.01 * * \\
(.00)\end{array}$ \\
\hline Older adults & $\begin{array}{r}.01 * * \\
(.01)\end{array}$ & $\begin{array}{r}.06 * * \\
(.01)\end{array}$ & $\begin{array}{r}.00 * * \\
(.00)\end{array}$ & $\begin{array}{r}.01 * * \\
(.01)\end{array}$ & $\begin{array}{r}.01 * * \\
(.01)\end{array}$ & $\begin{array}{r}.01 * * \\
(.01)\end{array}$ & $\begin{array}{r}.01 * * \\
(.01)\end{array}$ & $\begin{array}{r}.01 * * \\
(.01)\end{array}$ & $\begin{array}{r}.00 * * \\
(.00)\end{array}$ \\
\hline $\begin{array}{l}\text { Rural } \\
\text { residence }\end{array}$ & $\begin{array}{r}-.18 * * \\
(.14)\end{array}$ & $\begin{array}{r}-.34 * * \\
(.27)\end{array}$ & $\begin{array}{r}-.31 * * \\
(.25)\end{array}$ & $\begin{array}{r}-.07 * * \\
(.04)\end{array}$ & $\begin{array}{r}.28 * * \\
(.16)\end{array}$ & $\begin{array}{r}.06^{* *} \\
(.03)\end{array}$ & $\begin{array}{r}.19^{* *} \\
(.12)\end{array}$ & $\begin{array}{l}-.53 * * \\
(0.41)\end{array}$ & $\begin{array}{r}-.41 * * \\
(.38)\end{array}$ \\
\hline $\begin{array}{l}\text { In the labor } \\
\text { force }\end{array}$ & $\begin{array}{l}.31 * \\
(.24)\end{array}$ & $\begin{array}{r}.42 * * \\
(.39)\end{array}$ & $\begin{array}{r}.12 * * \\
(.04)\end{array}$ & $\begin{array}{l}.14 * \\
(.08)\end{array}$ & $\begin{array}{r}.14 * * \\
(.11)\end{array}$ & $\begin{array}{r}.09 * * \\
(.05)\end{array}$ & $\begin{array}{l}.08 * \\
(.03)\end{array}$ & $\begin{array}{r}-.05 * * \\
(.01)\end{array}$ & $\begin{array}{r}-.09 * * \\
(.04)\end{array}$ \\
\hline $\begin{array}{l}\text { Out of the } \\
\text { labor force }\end{array}$ & $\begin{array}{r}-.25 * * \\
(.19)\end{array}$ & $\begin{array}{r}-.33 * * \\
(.24)\end{array}$ & $\begin{array}{r}-.38 * * \\
(.26)\end{array}$ & $\begin{array}{r}-.37 * * \\
(.29)\end{array}$ & $\begin{array}{r}.18 * * \\
(.14)\end{array}$ & $\begin{array}{r}.04 * * \\
(.01)\end{array}$ & $\begin{array}{r}.29 * * \\
(.22)\end{array}$ & $\begin{array}{r}-.59 * * \\
(.46)\end{array}$ & $\begin{array}{r}-.54 * * \\
(.41)\end{array}$ \\
\hline Wald Chi2 & 5396 & 9168 & 7459 & 5798 & 4261 & 5347 & 11291 & 12109 & 10895 \\
\hline $\begin{array}{l}\text { Log } \\
\text { likelihood }\end{array}$ & -12929 & -7721 & -4739 & -1321 & -561 & -672 & -7965 & -4514 & -6596 \\
\hline Prob>chi2 & .00 & .00 & .00 & .00 & .00 & .00 & .00 & .00 & .00 \\
\hline
\end{tabular}

Source: Authors' elaboration on STATA output. *** $\mathrm{p}<0.1, * * \mathrm{p}<0.01, * \mathrm{p}<0.05$.

In addition, those who have an account also tend to be richer and to actively participate in the labor force; thereby having a greater capacity to save in different ways. This supports our findings according to which women are less likely to report having saved any money in the past year.

The options for saving however go beyond doing so at a financial institution. Semi-formal savings methods offer products or provide benefits that are not available through formal saving by reducing the gap between women and men. Our results suggest that being a woman increases the probability to save in a semi-formally way by using a savings club or a person outside the family. This is in line with Demirgüç-Kunt et al. (2018) showing that semi-formal savings methods are widely used among unbanked adults, including 35 million women worldwide.

Finally, the results suggest that being a woman reduces the probability of borrowing money regardless of purpose and the source (including financial institutions, savings clubs, and family or friends).

In line with Zins and Weill (2016), we find that wealth is positively correlated with financial inclusion, leaving a gap between the richest and poorest. Adults in the poorest 40 percent of households are unbanked; they are less likely to have an account at a financial institution or through a mobile money provider. In addition, they are less likely to have credit cards, savings as well as borrow money except for health or medical purposes.

Even adults in the richest 60 percent of households show a significant and negative relationship with account ownership and borrowing activity (except again for health or medical purposes). However, they are more likely to own a credit card and save money both formally and semi-formally. 
The results show that education plays an essential role in financial inclusion. Regardless of the level (primary or secondary), education significantly and positively determines the possibility of owning credit cards and accounts at financial institutions or through mobile money providers. Among all adults, those with primary education (or less) are more likely to save or set aside any money for any reason and using any mode of saving in the past 12 months, including savings clubs or people outside the family. Adults with secondary education (or more) are more likely to save (formally and not) and borrow money for education or school fees.

The gap between the age groups varies widely among developed and developing economies. In developed economies, adults are more likely to have an account and to belong to the older age group while in developing economies adults are more likely to not have an account and to belong to the younger age group (Demirgüç-Kunt et al., 2018).

Our results show no major difference in accounts and credit cards ownership as well as savings activity between the age groups. However, older adults are more likely to borrow money than young ones.

The gap between rural and urban areas can be seen in the lower probability of the rural population to own accounts and credit cards, as well as to formally save and borrow money except for health purposes. Not surprisingly, financial inclusion tends to be higher in urban areas where people can benefit from far broader access to financial services.

The same situation occurs for the employment status between adults who are active in the labor force (either employed or seeking work) and those who are out of the labor force. Working adults are more in need of financial services to receive their wages or saving their earnings.

Table 3 shows the analysis of factors associated with eight barriers leading to financial exclusion.

Table 3. Determinants of barriers to financial inclusion (robust standard errors in parentheses).

\begin{tabular}{|c|c|c|c|c|c|c|c|c|}
\hline & $\begin{array}{r}\text { Too far } \\
\text { away }\end{array}$ & $\begin{array}{r}\text { Too } \\
\text { expensive }\end{array}$ & $\begin{array}{r}\text { Lack of } \\
\text { documentation }\end{array}$ & $\begin{array}{r}\text { Lack } \\
\text { of trust }\end{array}$ & $\begin{array}{r}\text { Lack of } \\
\text { money }\end{array}$ & $\begin{array}{r}\text { Family } \\
\text { member has } \\
\text { an account }\end{array}$ & $\begin{array}{r}\text { No need } \\
\text { financial } \\
\text { services } \\
\end{array}$ & $\begin{array}{r}\text { Religious } \\
\text { reasons }\end{array}$ \\
\hline \multirow[t]{2}{*}{ Female } & $-.21 * *$ & $-.17 * *$ & $-.09 *$ & $-.22 * *$ & $.09 *$ & $.33^{* * *}$ & $-.14 * *$ & $.16^{* *}$ \\
\hline & $(.14)$ & $(.09)$ & $(.06)$ & $(.14)$ & $(.04)$ & $(.24)$ & $(.09)$ & $(.09)$ \\
\hline \multirow[t]{2}{*}{ Poorest $40 \%$} & $.14 * *$ & $.13 * *$ & $.08 *$ & $-0.27 * *$ & $.34 * *$ & $-.27 * *$ & $-.19 * *$ & $-.22 * *$ \\
\hline & $(.07)$ & $(.06)$ & $(.07)$ & $(.018)$ & $(.25)$ & $(.23)$ & $(.08)$ & $(.17)$ \\
\hline \multirow[t]{2}{*}{ Richest $60 \%$} & $.02 *$ & $.01 *$ & -.12 & $-.02 * *$ & $.08 * *$ & $-.11 * *$ & $-.02 * *$ & $-.21 * *$ \\
\hline & $(.01)$ & $(.00)$ & $(.07)$ & $(.01)$ & $(.03)$ & $(.09)$ & $(.01)$ & $(.19)$ \\
\hline Primary & $-.12 * *$ & $-.39 * *$ & $.01 *$ & $-.37 * *$ & $.16^{* *}$ & $-.79 * *$ & $-.34 * *$ & $-.43 * *$ \\
\hline $\begin{array}{l}\text { education or } \\
\text { less }\end{array}$ & $(.07)$ & $(.22)$ & $(.00)$ & $(.22)$ & $(.11)$ & $(.54)$ & $(.18)$ & $(.22)$ \\
\hline Secondary & $-.19 * *$ & $-.08 * *$ & $.00 *$ & $-.41 * *$ & .03 & $-.23 * *$ & $-.17 * *$ & $-.51 * *$ \\
\hline $\begin{array}{l}\text { education or } \\
\text { more }\end{array}$ & $(.12)$ & $(.03)$ & $(.00)$ & $(.33)$ & $(.01)$ & $(.14)$ & $(.12)$ & $(0.38)$ \\
\hline Young & $-.02 * *$ & $-.01 * *$ & $-.01 * *$ & $-.01 * *$ & $.01 * *$ & $-.04 * *$ & $-.02 * *$ & $-.02 * *$ \\
\hline adults & $(.01)$ & $(.00)$ & $(.00)$ & $(.00)$ & $(.00)$ & $(.01)$ & $(.01)$ & $(.01)$ \\
\hline \multirow[t]{2}{*}{ Older adults } & $.00 * *$ & $.00 * *$ & $-.06 * *$ & $.02 * *$ & $.01 * *$ & $.01 * *$ & $.00 * *$ & $.01 * *$ \\
\hline & $(.00)$ & $(.00)$ & $(.02)$ & $(.01)$ & $(.00)$ & $(.00)$ & $(.00)$ & $(.00)$ \\
\hline Rural & $.34 * *$ & $.19 * *$ & $.28 * *$ & $.02 * *$ & $.06^{* *}$ & $.49 * *$ & $.16^{* *}$ & $.37 * *$ \\
\hline residence & $(.18)$ & $(.11)$ & $(.21)$ & $(.01)$ & $(.05)$ & $(.34)$ & $(.09)$ & $(.24)$ \\
\hline In the labor & $.21 * *$ & $-.05 * *$ & $-.36 * *$ & $-.04 * *$ & $-.01 * *$ & .05 & $-.27 * *$ & $.33 * *$ \\
\hline force & $(.12)$ & $(.04)$ & $(.29)$ & $(.03)$ & $(.00)$ & $(.03)$ & $(.14)$ & $(.21)$ \\
\hline Out of the & $.05 * *$ & $.09 * *$ & $.08 * *$ & $.01 * *$ & $.04 * *$ & $.18 * *$ & $.38 * *$ & $.42 * *$ \\
\hline labor force & $(.01)$ & $(.07)$ & $(.06)$ & $(.00)$ & $(.01)$ & $(.09)$ & $(.31)$ & $(.29)$ \\
\hline Wald Chi2 & 5762 & 3319 & 5591 & 5491 & 1664 & 5294 & 2396 & 6763 \\
\hline $\begin{array}{l}\text { Log } \\
\text { likelihood }\end{array}$ & -4083 & -6417 & -4691 & -4903 & -7309 & -4681 & -6937 & -3637 \\
\hline Prob $>$ chi2 & .00 & .00 & .00 & .00 & .00 & .00 & .00 & .00 \\
\hline
\end{tabular}

Source: Authors' elaboration on STATA output. ** $p<0.01, * \mathrm{p}<0.05$ 
The results suggest that the main barrier to the financial inclusion of women is represented by the fact that another family member already has an account. The lack of enough money and religious reasons are other important barriers for women especially in economies with a predominantly Muslim population and Sharia-compliant financial institutions. Lack of need, distrust in the financial system and documentation requirements also hamper account ownership among women followed by distance and high costs. Education and young age are is positively associated only with the lack of money and documentation requirements. This confirms that literacy can help decrease barriers to financial inclusion.

Education, wealth, young age as well as employment and urban residence are negatively associated with most of the barriers to financial inclusion. Most of the unbanked adults have more than 25 years old and low educational attainment; they are unemployed or not looking for work; they reside in rural areas and belong to the poorest 40 percent of households.

\section{Concluding remarks}

Using the World Bank's Global Findex database, we find evidence that economic and cultural discrimination is responsible for the women's modest financial inclusion. The results from probit models add to the literature and indicate that the gender inequality in the Middle East and North Africa could be overcome by ensuring the establishment of the right financial services and tools and the removal of cultural and economic barriers. This would imply direct actions by policymakers and financial institutions.

\section{References}

Abdu, M., Buba, A., Adamu, I., and Muhammad, T. (2015) Drivers of financial inclusion and gender gap in Nigeria, The Empirical Econometrics and Quantitative Economics Letters (EEQEL), 4(4), 186-199.

Arnold, J., and Gammage, S. (2019) Gender and financial inclusion: the critical role for holistic programming, Development in Practice, 29(8), 965-973.

Demirgüç-Kunt, A., Klapper, L., Singer, D., Ansar, S., Hess, J. (2018) Global Findex Database 2017: Measuring Financial Inclusion and the Fintech Revolution, Washington, DC: World Bank.

Ghosh, S., and Vinod, D. (2017) What constrains financial inclusion for women? Evidence from Indian micro data, World Development, 92, 60-81.

Holloway, K., Z. Niazi, and R. Rouse. (2017) Women's Economic Empowerment Through Financial Inclusion: A Review of Existing Evidence and Remaining Knowledge Gaps. New Haven, CT: Innovations for Poverty Action.

Klapper, L., and J. Hess. (2016) Financial Inclusion and Women's Economic Empowerment, Briefing for the UN Secretary-General's High-Level Panel on Women's Economic Empowerment.

Koch, K., A. Stupnytska, A. MacBeath, S. Lawson, and K. Matsui. (2014) Giving Credit Where it is Due; How Closing the Credit Gap for Women-Owned SMEs can Drive Global Growth. New York: Goldman Sachs Global Markets Institute.

Suri, T. and W. Jack. (2016) The long-run poverty and gender impacts of mobile money, Science, 354(6317), 1288-1292.

Zins, A., and Weill, L. (2016) The determinants of financial inclusion in Africa, Review of Development Finance, 6(1), 46-57. 